\title{
Psoriasin, one of several new proteins identified in nasal lavage fluid from allergic and non-allergic individuals using 2-dimensional gel electrophoresis and mass spectrometry Malin Bryborn*, Mikael Adner and Lars-Olaf Cardell
}

Address: Laboratory of Clinical and Experimental Allergy, Department of Otorhinolaryngology, Malmo University Hospital, Lund University, Malmo, Sweden

Email: Malin Bryborn* - malin.bryborn@med.lu.se; Mikael Adner - mikael.adner@med.lu.se; Lars-Olaf Cardell - lars-olaf.cardell@med.lu.se

* Corresponding author

Published: 19 October 2005

Respiratory Research 2005, 6:118 doi:10.1186/1465-9921-6-118
Received: 05 April 2005

Accepted: 19 October 2005

This article is available from: http://respiratory-research.com/content/6/1/II8

(c) 2005 Bryborn et al; licensee BioMed Central Ltd.

This is an Open Access article distributed under the terms of the Creative Commons Attribution License (http://creativecommons.org/licenses/by/2.0), which permits unrestricted use, distribution, and reproduction in any medium, provided the original work is properly cited.

\begin{abstract}
Background: Extravasation and luminal entry of plasma occurs continuously in the nose. This process is markedly facilitated in patients with symptomatic allergic rhinitis, resulting in an increased secretion of proteins. Identification of these proteins is an important step in the understanding of the pathological mechanisms in allergic diseases. DNA microarrays have recently made it possible to compare mRNA profiles of lavage fluids from healthy and diseased patients, whereas information on the protein level is still lacking.

Methods: Nasal lavage fluid was collected from II patients with symptomatic allergic rhinitis and II healthy volunteers. 2-dimensional gel electrophoresis was used to separate proteins in the lavage fluids. Protein spots were picked from the gels and identified using mass spectrometry and database search. Selected proteins were confirmed with western blot.

Results: 61 spots were identified, of which 21 were separate proteins. 6 of these proteins (psoriasin, galectin-3, alpha enolase, intersectin-2, Wnt-2B and hypothetical protein MGC33648) had not previously been described in nasal lavage fluids. The levels of psoriasin were markedly down-regulated in allergic individuals. Prolactin-inducible protein was also found to be downregulated, whereas different fragments of albumin together with Ig gamma 2 chain $\mathrm{c}$ region, transthyretin and splice isoform I of Wnt-2B were up-regulated among the allergic patients.

Conclusion: The identification of proteins in nasal lavage fluid with 2-dimensional gelelectrophoresis in combination with mass spectrometry is a novel tool to profile protein expression in allergic rhinitis and it might prove useful in the hunt for new therapeutic targets or diagnostic markers for allergic diseases. Psoriasin is a potent chemotactic factor and its downregulation during inflammation might be of importance for the outcome of the disease.
\end{abstract}

\section{Background}

Increased vascular permeability and plasma exudation are important characteristics of allergic rhinitis leading to an increased amount of secreted proteins [1,2]. Earlier inves- tigations with DNA microarray analysis [3] have described the gene expression in nasal mucosa. However, there is a considerable interest to identify some of the secreted proteins for a better understanding of the pathological 
processes and possibly to find new therapeutical targets or diagnostic markers for the disease.

Combining 2-dimensional gel electrophoresis (2-DE) with mass spectrometry (MS) have recently emerged as a method for identifying proteins in different biological samples. In short, proteins are separated in the first dimension according to their isoelectric points (pI) and then in the second dimension according to their molecular weight using SDS-PAGE. Each spot on the SDS-PAGE gel corresponds to one protein. The spots can be excised and further analysed and identified using mass spectrometry and database searching [4]. 2-DE together with MS has previously been used to investigate the protein content in nasal lavage fluid (NLF) [5] and a study of differences in the NLF protein content from smokers and nonsmokers [6] is recently reported. However, changes in relation to allergic airway diseases have so far not been probed. The main purpose of this study was to use 2-DE in combination with MS and database search in order to map and identify the broad range of secreted proteins in NLF from individuals allergic to pollen (birch/timothy) and to compare that with NLF from non-allergic healthy individuals.

\section{Materials and methods Skin prick test}

Skin prick tests (SPT) were performed with a standard panel of 10 common airborne allergens (ALK, Copenhagen, Denmark) including pollen (birch, timothy and artemisia), house dust mites (D. Pteronyssimus and D. Farinae), molds (Cladosporium and Alternaria) and animal allergens (cat, dog and horse). SPT were performed on the volar side of the forearm with saline buffer as negative and histamine chloride $(10 \mathrm{mg} / \mathrm{ml})$ as positive controls. The diameter of the wheal reactions were measured after 20 min with a ruler.

\section{Subjects}

The study included 11 patients ( 6 women) with symptomatic birch and/or grass pollen induced intermittent allergic rhinitis and 11 healthy volunteers ( 7 women), serving as controls. The mean age of patients and controls was 43 (26-55) and 41 (24-55) years, respectively. The diagnosis of birch and/or grass pollen induced allergic rhinitis was based on a positive history of intermittent allergic rhinitis for at least 2 years and positive SPT to birch and/or grass. All patients were classified as having severe symptoms (itchy nose and eyes, sneezing, nasal secretion and nasal blockage) during pollen season and they had all been treated with antihistamines and nasal steroids during pollen seasons previous years. Patients had no continuous symptoms of asthma and they did not take any asthma medication. All patients presented a wheal reaction diameter $>3 \mathrm{~mm}$ towards birch or timothy in SPT (roughly cor- reponding to a $3+$ or $4+$ reaction when compared with histamine [7]). Exclusion criteria included a history of perennial symptoms, upper airway infection for the last 2 weeks before the time of visit and treatment with local or systemic corticosteroids during the last 2 months. The controls were all symptom-free, had no history of allergic rhinitis and had negative SPT to the standard panel of allergens as described above. They had no history of upper airway infection for 2 weeks before the time of visit and they were all free of medication. The study was approved by the Ethics Committee of the Medical Faculty, Lund University.

\section{Sample collection and preparation}

Nasal lavage fluid was collected during either birch pollen ( 9 patients) or grass pollen season (2 patients). Patients were included when they had experienced substantial symptoms of rhinoconjunctivitis (itchy nose and eyes, sneezing, nasal secretion and nasal blockage) during at least 3 consecutive days. The majority of the patients were seen within 5-10 days after the first appearance of symptoms and a local pollen count.

Nasal lavage fluid was collected according to a previously described method [8]. After clearing of excess mucus from the nose sterile saline solution of room temperature was sprayed into both nostrils, respectively. The fluid was allowed to return passively and collected in a graded tube until $7 \mathrm{ml}$ was recovered. NLFs were centrifuged at 1750 $\mathrm{rpm}$ at $4^{\circ} \mathrm{C}$ for $10 \mathrm{~min}$ to remove the cell content and the supernatants were stored at $-70^{\circ} \mathrm{C}$ until sample preparation.

Before concentration of the samples NLFs were thawed and centrifuged at $12300 \mathrm{rpm}$ at $4{ }^{\circ} \mathrm{C}$ for $20 \mathrm{~min}$ to remove debris. Using Vivaspin 6 and Vivaspin 500 concentrators (Vivascience, Hannover, Germany) supernatants were concentrated and desalted. The protein concentration was determined using BCA Protein Assay Kit (Pierce Biotechnology, Rockford, USA) and resulted in a protein concentration of $1572-5625 \mu \mathrm{g} / \mathrm{ml}$ for healthy individuals and $1833-7867 \mu \mathrm{g} / \mathrm{ml}$ for allergic individuals. NLFs were stored at $-70^{\circ} \mathrm{C}$ until analysed.

\section{2-DE analysis}

Samples were mixed with rehydration solution containing $8 \mathrm{M}$ Urea, 2\% CHAPS, $2.8 \mathrm{mg} / \mathrm{ml}$ DTT (Sigma-Aldrich, Steinheim, Germany), 0.5\% IPG Buffer (pH 3-10) (Amersham Biosciences, Uppsala Sweden) and a small amount of bromophenol blue. For analytical gels $150 \mu \mathrm{g}$ of protein was added to a final volume of $450 \mu \mathrm{l}$ for each sample. For the preparative gels, one for healthy and one for allergic samples, $600 \mu \mathrm{g}$ from a pool of samples was used. To be able to load as much as $600 \mu \mathrm{g}$ on the preparative gels pooled samples were further concentrated using 
Microcon YM-3 (Millipore, Billerica, USA) before added to rehydration solution. Samples were incubated for approximately $15 \mathrm{~min}$ in room temperature in order to completely solubilize and denature the proteins. Samples were centrifuged at $13000 \mathrm{rpm}$ for $10 \mathrm{~min}$ and thereafter loaded onto $24 \mathrm{~cm} \mathrm{3-10} \mathrm{non} \mathrm{linear} \mathrm{IPG} \mathrm{strips} \mathrm{(Amersham}$ Biosciences, Uppsala, Sweden). In-gel rehydration and isoelectric focusing (IEF) was performed over night ( $60000 \mathrm{Vh})$ using Ettan IPGphor Isoelectric Focusing System (Amersham Biosciences, Uppsala, Sweden). After IEF strips were stored at $-70^{\circ} \mathrm{C}$ until analysed. The IPG strips were equilibrated in SDS equilibration buffer (75 $\mathrm{mM}$ Tris, $6 \mathrm{M}$ Urea, 30\% glycerol, 2\% SDS and $0.002 \%$ bromophenol blue (Sigma-Aldrich, Steinheim, Germany)) for $2 \times 15 \mathrm{~min}$. DTT $(10 \mathrm{mg} / \mathrm{ml}$ ) (Sigma-Aldrich, Steinheim, Germany) was added to the first and iodoacetamide $(25 \mathrm{mg} / \mathrm{ml}$ ) (Sigma- Aldrich, Steinheim, Germany) to the second equilibration step. After equilibration strips were loaded onto laboratory-made $12.5 \%$ acrylamide second dimension gels. SDS-PAGE was performed at constant effect $(10 \mathrm{~W} /$ gel $)$ for about $4 \mathrm{~h}$ and 30 min using the Ettan DALT II system (Amersham Biosciences).

\section{Staining of gels and gel image analysis}

Second dimension gels were fixed in 30\% ethanol and $10 \%$ acetic acid over night, washed $4 \times 30 \mathrm{~min}$ in $20 \%$ ethanol and stained with the fluorescent dye ruthenium II tris-bathophenantroline disulfonate $(1 \mu \mathrm{M})$ for about $6 \mathrm{~h}$. Thereafter gels were destained in $40 \%$ ethanol and $10 \%$ acetic acid over night and washed with double distilled water for about $4 \times 30-60 \mathrm{~min}$ [9]. All incubation and washing steps were performed with gentle agitation. Gels were kept dark in double distilled water at $4{ }^{\circ} \mathrm{C}$ until scanned. The gels were automatically scanned using a robotic system together with a 9410 Typhoon scanner (488 nm laser) from Amersham Biosciences [10] and the gel images were analysed using the computer softwares Image master 2D Platinum (Amersham Biosciences) and Ludesi 2D Interpreter (Ludesi AB, Lund, Sweden). The volume in each spot was calculated as integrated optical density over the spot's area. The amount of protein in each spot was expressed as \%VOL (ppm), that is the volume for the spot divided with the total volume for all spots in the gel.

\section{Spot picking, protein digestion and MALDI-TOF (Matrix Assisted Laser Desorption Ionization-Time Of Flight) analysis}

Using the Ettan spot handling workstation (Amersham Biosciences) selected spots were automatically cut from the preparative gels, destained and enzymatically digested with trypsin (porcine Sequencing Grade Modified Trypsin, Promega, Madison, USA). The tryptic peptides were then spotted onto a MALDI target plate [11]. The
MALDI target plates were loaded in a Micromass M@ldi MALDI-TOF mass spectrometer (Waters, Milford, USA) for analysis of the peptide masses.

\section{Database search}

Peptide masses retrieved from MALDI-TOF analysis spectra were submitted to a database (IPI human 1.38) [12] by using the search engine PIUMS [13]. The following matcher parameters were used: constant modification of cysteine by carbamidomethylation, variable modification of methionine by oxidation and maximum 1 missed cleavage for trypsin. A protein hit was considered significant if the PIUMS quality score was $\geq 4.7$, which corresponds to an expectation value of 0.01 . A search in IPI human 1.38 was also done using the search engine Mascot and the results from this search were compared with the results from PIUMS.

\section{Western blot}

NLFs were mixed with SDS sample buffer, heated at 95$100^{\circ} \mathrm{C}$ for $5 \mathrm{~min}$ and centrifuged at $10000 \mathrm{rpm}$ for 10 min. Equal amounts of the samples were loaded onto NuPAGE Bis-Tris 4-12\% gel (Invitrogen, Carlsbad, USA), separated by electrophoresis (Mini vertical gel system, Thermo EC, Waltham, USA), and blotted to ImmobilonP PVDF membranes (Millipore, Billerica, USA). Membranes were blocked in buffer 1 (Tris- $\mathrm{HCl} 10 \mathrm{mM} \mathrm{pH} 7.4$, $\mathrm{NaCl} 0.9 \%$ and dry milk $5 \%$ ) and then incubated overnight with primary antibody $(1 \mu \mathrm{g} / \mathrm{ml})$ against psoriasin, galectin-3 (Abcam, Cambridge, UK), Wnt-2B (Zymed, South San Francisco, USA) and alpha enolase (Santa Cruz, Santa Cruz, USA), respectively. Membranes were washed 2 times with buffer 1 followed by incubation for approximately 2 h with HRP conjugated secondary antibody (50 $\mathrm{ng} / \mathrm{ml}$ ). After 2 washes with buffer 2 (Tris- $\mathrm{HCl} 10 \mathrm{mM} \mathrm{pH}$ 7.4, $\mathrm{NaCl} 0.9 \%$ and Tween 20 0.05\%) membranes were incubated for $5 \mathrm{~min}$ in SuperSignal West Pico solution (Pierce Biotechnology, Rockford, USA). The chemiluminescence was detected using MAN-X X-ray system (Fujifilm Science Imaging systems, USA). Developed films for quantitative analysis were scanned and analysed in ImageQuant (Molecular dynamics, Sunnyvale, USA). There were no antibodies available against hypothetical protein MGC33648 and the relevant fragment of intersectin-2. Hence, these proteins could not be assessed with western blot.

\section{Statistical analysis}

All values were expressed as mean values \pm SEM. Statistical analysis of the protein expression was performed in Ludesi 2D interpreter (Ludesi AB) using one-way ANOVA. 


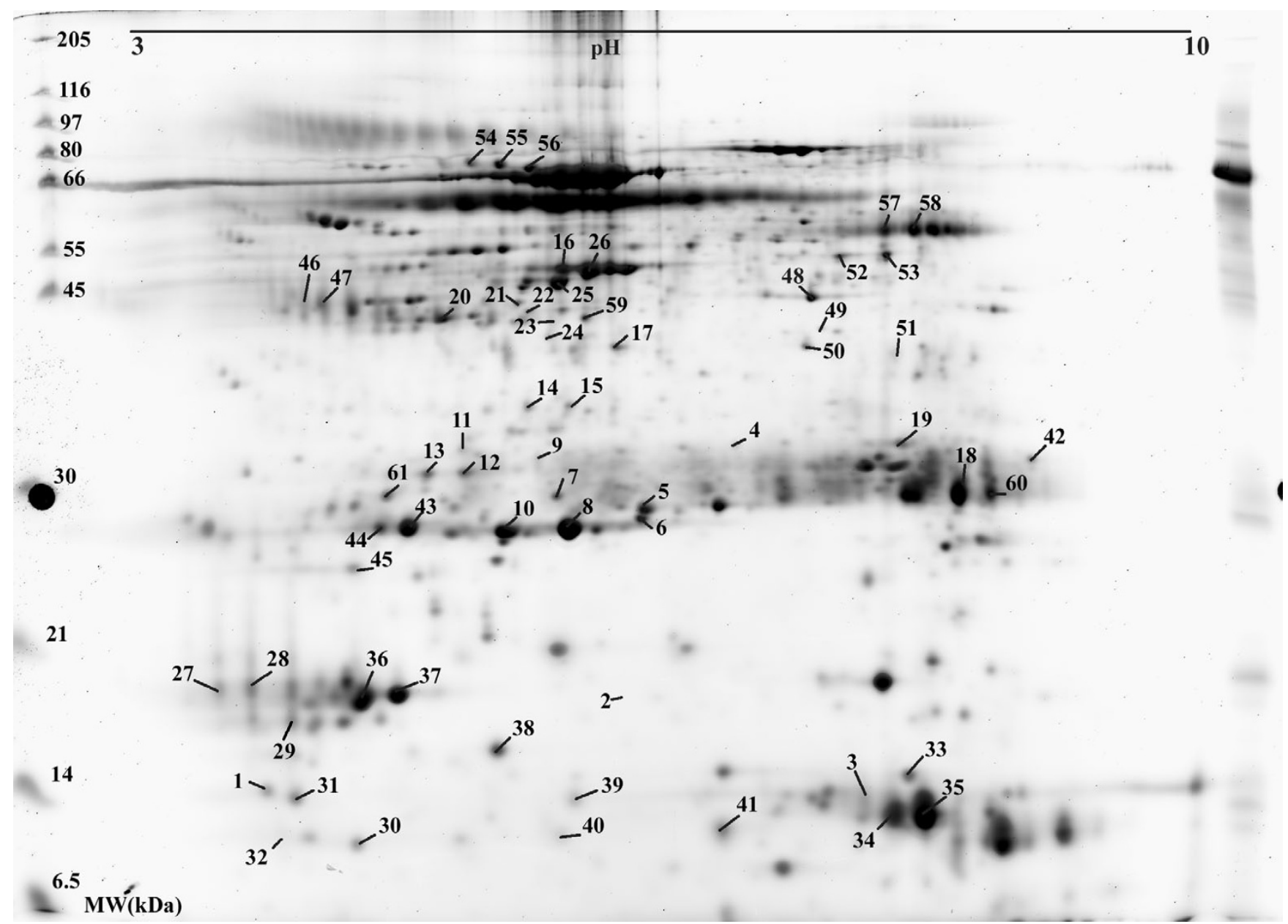

Figure I

2-DE protein pattern for NLF from a healthy non-allergic individual. The protein name for each numbered spot is presented in table I.

\section{Results}

Novel proteins in nasal lavage fluid

Of the spots picked from the 2D-gels and submitted to MALDI-TOF analysis 61 spots were identified (figure 1 and table 1). 21 of these were identified as separate proteins. The majority of the proteins has previously been identified in NLF $[5,6,14]$ but this is the first study where psoriasin, galectin-3, alpha enolase, intersectin-2, Wnt-2B and hypothetical protein MGC33648 have been recognized. The occurrence of psoriasin, galectin-3, Wnt-2B and alpha enolase was confirmed with western blot (figure 2).

\section{Differences in protein expression between allergic and non-allergic individuals}

14 spots exhibited a clear difference in the protein content when the material from allergic and non-allergic individ- uals was compared (table 2). 8 of these spots were identified as different fragments of albumin and all these were up-regulated in allergic individuals (1.8- to 2.6-fold). Wnt-2B (splice isoform 1), transthyretin and Ig gamma-2 chain c region were also found to be up-regulated in allergic compared to non-allergic individuals $(2.5-, 1.6-$ and 2.1-fold, respectively). In contrast, prolactin-inducible protein and two forms of psoriasin were found to be down-regulated in allergic individuals $(2.0-, 2.0-$ and 3.4fold, respectively). The psoriasin levels in nasal lavage fluids from three patients with allergic rhinitis and three controls were also assessed using western blot analysis (figure 3A). Quantitative analysis revealed reduced levels among the allergic patients; $19962 \pm 5410$ for the non-allergic individuals compared to $6834 \pm 2258$ for the allergic individuals (figure $3 \mathrm{~B}$ ). 
Table I: Identified proteins in nasal lavage fluid from allergic and non-allergic individuals.

\begin{tabular}{|c|c|c|c|c|}
\hline Gel no. & Protein & $\begin{array}{l}\text { Accession no. } \\
\text { (Swissprot/IPI) }\end{array}$ & MW (kDa) (theoretical) & pl (theoretical) \\
\hline 1 & Albumin & $\underline{P} 02768$ & 69.4 & 5.9 \\
\hline 2 & Albumin & P02768 & 69.4 & 5.9 \\
\hline 3 & Albumin & P02768 & 69.4 & 5.9 \\
\hline 4 & Albumin & $\underline{P 02768}$ & 69.4 & 5.9 \\
\hline 5 & Albumin & $\underline{\mathrm{P} 02768}$ & 69.4 & 5.9 \\
\hline 6 & Albumin & $\overline{P 02768}$ & 69.4 & 5.9 \\
\hline 7 & Albumin & $\overline{P 02768}$ & 69.4 & 5.9 \\
\hline 8 & Albumin & $\overline{\mathrm{P} 02768}$ & 69.4 & 5.9 \\
\hline 9 & Albumin & $\underline{P 02768}$ & 69.4 & 5.9 \\
\hline 10 & Albumin & P02768 & 69.4 & 5.9 \\
\hline 11 & Albumin & $\overline{\mathrm{P} 02768}$ & 69.4 & 5.9 \\
\hline 12 & Albumin & $\overline{P 02768}$ & 69.4 & 5.9 \\
\hline 13 & Albumin & $\overline{\mathrm{P} 02768}$ & 69.4 & 5.9 \\
\hline 14 & Albumin & $\mathrm{P} 02768$ & 69.4 & 5.9 \\
\hline 15 & Albumin & $\mathrm{P} 02768$ & 69.4 & 5.9 \\
\hline 16 & Albumin & $\mathrm{P} 02768$ & 69.4 & 5.9 \\
\hline 17 & Albumin & P02768 & 69.4 & 5.9 \\
\hline 18 & Albumin & $\underline{\mathrm{IPI}} \overline{00216773}$ & 45.2 & 6.0 \\
\hline 19 & Albumin & IPI00384697 & 47.4 & 6.3 \\
\hline 20 & Albumin & IPI00384697 & 47.4 & 6.3 \\
\hline 21 & Albumin & IPI00384697 & 47.4 & 6.3 \\
\hline 22 & Albumin & IPI00384697 & 47.4 & 6.3 \\
\hline 23 & Albumin & IPI00384697 & 47.4 & 6.3 \\
\hline 24 & Albumin & IPI00384697 & 47.4 & 6.3 \\
\hline 25 & Albumin & IPI00384697 & 47.4 & 6.3 \\
\hline 26 & Albumin & $\underline{\mathrm{IPI} 00384697}$ & 47.4 & 6.3 \\
\hline 27 & Prolactin-inducible protein & $\mathrm{PI} 2273$ & 16.6 & 8.3 \\
\hline 28 & Prolactin-inducible protein & $\mathrm{PI} 2273$ & 16.6 & 8.3 \\
\hline 29 & Prolactin-inducible protein & $\overline{\mathrm{P} 12273}$ & 16.6 & 8.3 \\
\hline 30 & Prolactin-inducible protein & $\mathrm{PI} 2273$ & 16.6 & 8.3 \\
\hline 31 & Cystatin S & P01036 & 16.2 & 4.9 \\
\hline 32 & Cystatin S & $\overline{P 01036}$ & 16.2 & 4.9 \\
\hline 33 & Cystatin SN & $\overline{P 01037}$ & 18.8 & 6.8 \\
\hline 34 & Hemoglobin beta chain & P6887I & 16.0 & 7.3 \\
\hline 35 & Hemoglobin beta chain & $\overline{P 68871}$ & 16.0 & 7.3 \\
\hline 36 & $\begin{array}{l}\text { Intersectin 2, } \\
\text { (splice isoform 2) }\end{array}$ & Q9NZM3-2 & 190.5 & 8.4 \\
\hline 37 & Lipocalin-I & $\underline{\mathrm{P} 31025}$ & 19.3 & 5.4 \\
\hline 38 & Transthyretin & $\overline{\mathrm{P} 02766}$ & 15.9 & 5.5 \\
\hline 39 & Calgranulin B & $\overline{\mathrm{P} 06702}$ & 13.2 & 5.7 \\
\hline 40 & Psoriasin (S I 00A7) & P3II5I & 11.5 & 6.3 \\
\hline 41 & Psoriasin (S I 00A7) & $\mathrm{P3} 1151$ & 11.5 & 6.3 \\
\hline 42 & Galectin-3 & PI7931 & 26.2 & 8.6 \\
\hline 43 & Apolipoprotein AI & P02647 & 30.8 & 5.5 \\
\hline 44 & Apolipoprotein AI & $\mathrm{P} 02647$ & 30.8 & 5.5 \\
\hline 45 & Apolipoprotein AI & P02647 & 30.8 & 5.5 \\
\hline 46 & $\begin{array}{l}\text { Alpha-2 glycoprotein I, } \\
\text { zink }\end{array}$ & P2531I & 34.3 & 5.9 \\
\hline 47 & $\begin{array}{l}\text { Alpha-2 glycoprotein I, } \\
\text { zink }\end{array}$ & $\underline{P 25311}$ & 34.3 & 5.9 \\
\hline 48 & Serotransferrin & P02787 & 77.1 & 6.8 \\
\hline 49 & Serotransferrin & P02787 & 77.1 & 6.8 \\
\hline 50 & Serotransferrin & $\overline{\mathrm{P} 02787}$ & 77.1 & 6.8 \\
\hline 51 & Serotransferrin & P02787 & 77.1 & 6.8 \\
\hline 52 & Alpha enolase & $\overline{\mathrm{P} 06733}$ & 47.0 & 7.0 \\
\hline 53 & Alpha enolase & $\overline{P 06733}$ & 47.0 & 7.0 \\
\hline
\end{tabular}


Table I: Identified proteins in nasal lavage fluid from allergic and non-allergic individuals. (Continued)

\begin{tabular}{|c|c|c|c|c|}
\hline 54 & Hemopexin & P02790 & 51.7 & 6.5 \\
\hline 55 & Hemopexin & P02790 & 51.7 & 6.5 \\
\hline 56 & Hemopexin & P02790 & 51.7 & 6.5 \\
\hline 57 & Ig gamma 2 chain c region & $\overline{P 01859}$ & 35.9 & 7.7 \\
\hline 58 & $\begin{array}{l}\text { Wnt-2B protein } \\
\text { (splice isoform I) }\end{array}$ & Q93097-1 & 43.8 & 9.3 \\
\hline 59 & Fibrinogen beta chain & P02675 & 55.9 & 8.5 \\
\hline 60 & $\begin{array}{l}\text { Hypothetical protein } \\
\text { MGC } 33648\end{array}$ & $\underline{\mathrm{P} I 00 \mid 6858 \mathrm{I}}$ & 34.2 & 9.0 \\
\hline 61 & Actin, cytoplasmic I or 2 & P60709 & 41.7 & 5.3 \\
\hline
\end{tabular}

Proteins in bold are newly identified in NLF.
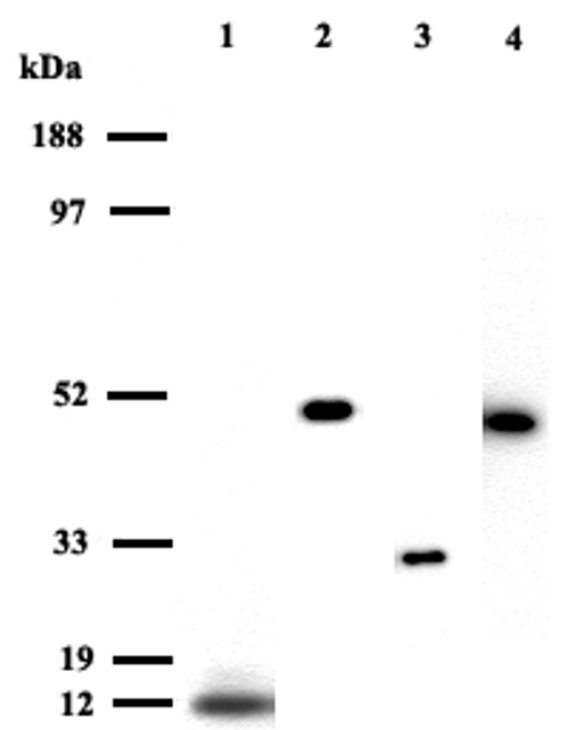

\section{Figure 2}

Western blot analysis of NLF from healthy non-allergic individuals. (I) Psoriasin, (2) Wnt-2B, (3) Galectin-3, (4) Enolase.

\section{Discussion}

The present study is the first where 2-DE in combination with MS has been used to study differences between allergic and non-allergic individuals. It reveals the presence of six novel NLF proteins: psoriasin, galectin-3, alpha enolase, intersectin-2, Wnt-2B and hypothetical protein MGC33648. One of these novel proteins, psoriasin, was markedly down-regulated in allergic individuals. The same was found for prolactin-inducible protein, whereas different fragments of albumin together with Ig gamma 2 chain $\mathrm{c}$ region, transthyretin and splice isoform 1 of Wnt$2 \mathrm{~B}$ were up-regulated among the allergic patients.
Increased vascular permeability and plasma exudation are important characteristics of allergic rhinitis resulting in an increased secretion of proteins. Several of the secreted proteins are collected in NLF and their identification is of importance for understanding pathological mechanisms in allergic rhinitis. DNA microarray technology is a relatively new method for analysing gene expression in different samples and it has recently been used in allergy research $[15,16]$. With DNA microarray technology it is possible to map genes that are up- or down-regulated in tissues or cells involved in allergic disease, something that might contribute to the identification of new pathological mechanisms or therapeutic targets [17]. However, all regulatory mechanisms are not operated at the transcriptional level. Hence, one of the disadvantages with DNA microarray technology is that the detected mRNA levels not always correlate with the actual protein levels in the sample. 2-DE together with MS-analysis is a powerful method to profile the protein expression in different samples. Two previous studies have used this methodology to analyse proteins in lavage fluids from the upper airways $[6,14]$. The present data now demonstrate that this approach also can be used to compare healthy and pathological samples in order to get an overview of which proteins that can be of importance for the development of allergic diseases.

Most of the 21 proteins identified in the present study correlate well with proteins found in NLF from normal, healthy individuals in previous studies $[5,6,14]$. However, 6 of the proteins (psoriasin, galectin-3, alpha enolase, intersectin-2, Wnt-2B and hypothetical protein MGC33648) have not previously been described in NLF. Psoriasin, also called S100A7, belongs to the S100 protein family and like other members in this family (for example calgranulin B) it has calcium-binding properties. It was first identified in psoriatic skin [18] where it is highly upregulated. Psoriasin is thought to be involved in inflammation since it is a potent chemotactic factor for CD4+ T lymphocytes and neutrophils [19]. Galectin-3 belongs to a family of $\beta$-galactoside-binding animal lectins [20]. It is 
Table 2: Proteins differently expressed in allergic and non-allergic individuals.

\begin{tabular}{|c|c|c|c|c|}
\hline Protein & No. & Non-allergic ${ }^{a}$ & Allergic $^{a}$ & Fold changes \\
\hline Psoriasin & 40 & $1831 \pm 425$ & $543 \pm 110 *$ & -3.4 \\
\hline Psoriasin & 41 & $7410 \pm 1675$ & $3689 \pm 650^{*}$ & -2.0 \\
\hline Prolactin-inducible protein & 29 & $2322 \pm 491$ & $1130 \pm 194^{*}$ & -2.0 \\
\hline Transthyretin & 38 & $1182 \pm 177$ & $1902 \pm 286^{*}$ & 1.6 \\
\hline Ig gamma 2 chain c region & 57 & $3493 \pm 590$ & $7349 \pm 1137 *$ & 2.1 \\
\hline $\begin{array}{l}\text { Wnt-2B protein (splice } \\
\text { isoform I) }\end{array}$ & 58 & $3360 \pm 668$ & $8405 \pm|76|^{*}$ & 2.5 \\
\hline Albumin fragment & 6 & $803 \pm 210$ & $1580 \pm 258^{*}$ & 2.0 \\
\hline Albumin fragment & 11 & $363 \pm 83$ & $957 \pm 247^{*}$ & 2.6 \\
\hline Albumin fragment & 15 & $386 \pm 99$ & $606 \pm 116^{*}$ & 2.4 \\
\hline Albumin fragment & 17 & $514 \pm 115$ & $927 \pm 86^{*}$ & 1.8 \\
\hline Albumin fragment & 21 & $407 \pm 74$ & $1008 \pm 183^{*}$ & 2.5 \\
\hline Albumin fragment & 23 & $139 \pm 50$ & $324 \pm 72^{*}$ & 2.3 \\
\hline Albumin fragment & 20 & $2135 \pm 374$ & $3991 \pm 638^{*}$ & 1.9 \\
\hline Albumin fragment & 4 & $219 \pm 54$ & $500 \pm 92 *$ & 2.3 \\
\hline
\end{tabular}

a The amount of protein is expressed as mean \%VOL (ppm) \pm SEM.

$* p<0.05$

expressed in mast cells, monocytes/macrophages, neutrophils and eosinophils. Although galectin-3 lacks signal peptide, it can be secreted [21] and it functions as chemotactic factor for monocytes and macrophages [22]. Galectin-3 also has the ability to bind Ig-E and increased mRNA levels for galectin-3 have been found in neutrophils derived from the blood of allergic patients [23]. Alpha enolase is a ubiquitous multifunctional enzyme involved in many different processes [24]. It has been reported as an important allergen in inhalant allergies to fungi [25] and specific IgE antibodies have been found in patients allergic to fungi [26], all corroborating the notion that alpha enolase might play a role in allergic reactions. One spot was identified as splice isoform 2 of intersectin-2, a cytoplasmic protein involved in endocytosis [27]. The spot identified is probably a degradation product of intersectin-2 since it is present at a much lower MW than the theoretical value. Wnt-2B is a developmental protein that might play a role as hematopoietic growth factor [28].

The role of these newly identified proteins in allergic rhinitis is not known and they all render further investigation. However, special attention might be drawn to the two different forms of psoriasin [29] found to be down-regulated during allergic rhinitis in the present study. Since allergic rhinitis is an inflammatory disease and psoriasin is a chemotactic factor for inflammatory cells one could have expected the opposite. One explanation for this reversed condition is that psoriasin in addition to its chemotactic properties has an other not yet discovered role in the inflammation process. In this context, it is also essential to recognize that inflammation is normally a self-resolving process with the existence of both positive and negative regulators that ultimately allow complete resolution and homeostasis. In the absence of resolution and clearance or in the event of a dampened healing response, persistent inflammation can arise in the form of tissue damage as associated with chronic disease. Thus, the down-regulation of psoriasin during the allergic inflammation could be of importance for the natural resolution of the disease.

Previous findings [23] have suggested that galectin-3 is involved in the inflammatory reaction seen in allergic patients. However, in the present study no differences in the galectin-3 content were seen when material from allergic and non-allergic individuals were compared. Alpha enolase was identified in two spots but any quantitative difference between allergic and non-allergic individuals could not be detected. In contrast, splice isoform 1 of Wnt-2B was found to be up-regulated (2.5-fold) among allergic individuals. Such an increase of the Wnt-2B secretion might be related to the increased growth and maturation stimulation of eosinophils and neutrophils often seen during the allergic inflammation.

In addition to the novel NLF proteins psoriasin and Wnt$2 \mathrm{~B}$, a group of other proteins were also found to be differently expressed during the allergic inflammation. There was a 2.0-fold decrease of one form of prolactin-inducible protein (PIP) in allergic individuals. PIP is expressed in exocrine organs like sweat, salivary and lacrimal glands [30]. The functions of PIP is not completely known but it has CD4-binding properties and is a strong inhibitor of $\mathrm{T}$ lymphocyte apoptosis [31]. A down-regulation of PIP might therefore be associated with an increased apoptosis of T lymphocytes, something that might contribute to a 
A

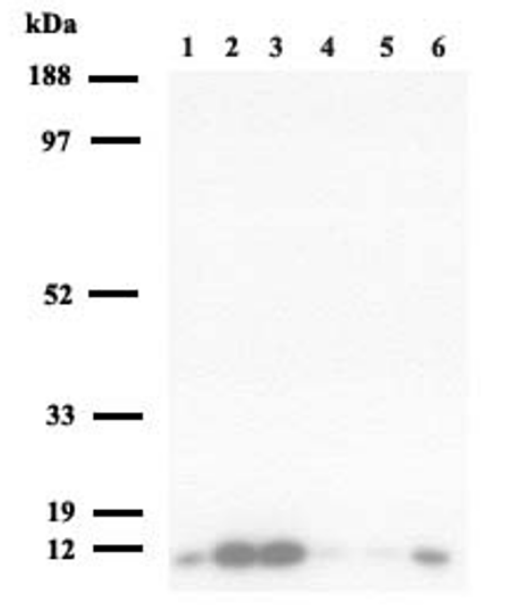

B

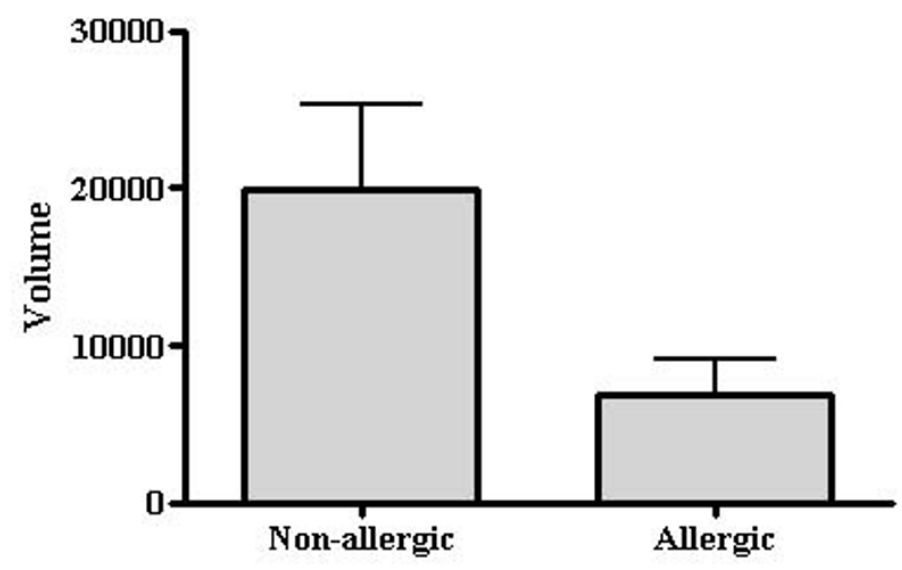

\section{Figure 3}

Expression analysis of psoriasin with western blot. A: Western blot analysis of NLF from three healthy non-allergic individuals $(\mathrm{I}-3)$ and three allergic individuals (4-6) demonstrating the levels of psoriasin. I $\mu \mathrm{g}$ of total protein was loaded in each lane. B: Quantitative analysis of western blot with ImageQuant (Molecular Dynamics, USA). Each data point represents the mean \pm SEM.

limitation of the inflammatory process. The theoretical pI for PIP is 8.3 but it was detected in the gel at a pI around 4-5. Without its signal peptide the theoretical pI decreases to 5.4 which is closer to our observation. Transthyretin, also called prealbumin, is a plasma protein involved in the transport of thyroxine and retinol [32]. The small upregulation of transthyretin detected in allergic individuals (1.6-fold) is probably due to the increased plasma exudation seen in allergic rhinitis [2].

Several of the spots were identified as the same protein. Hence, many proteins are present in different forms. The different forms may result from post-translational modifications like phosphorylation, glycosylation, acetylation or degradation of the proteins. All spots identified as albumin are probably different forms and fragments of albumin and since albumin is highly abundant in plasma this high amount of degradation products in NLF is expected. It is not surprising that a few of these fragments were up-regulated in allergic individuals since this only confirms previous findings that the secretion of albumin is increased in allergic individuals. Ig gamma 2 chain c region was also found to be up-regulated in allergic individuals which also confirms previous findings [33].

\section{Conclusion}

2-DE in combination with MS-analysis appears to be a powerful method to profile the protein expression and compare healthy samples with pathological samples. In this study both previously identified and newly identified proteins were detected in NLF using this method. Some of these proteins, like psoriasin, Wnt-2B and PIP were found to be differently expressed in allergic and non-allergic individuals. Further investigations are needed to explain the pathological significance of these proteins. It is possible that some of them can be defined as new therapeutic targets or diagnostic markers for allergic diseases.

\section{Competing interests}

The author(s) declare that they have no competing interests.

\section{Authors' contributions}

$\mathrm{MB}$ performed the sample preparation, 2-DE, gel image analysis, analysis of MALDI results, database search, western blot and drafted the manuscript. MA and LOC conceived the study, participated in its design and coordination and helped to draft the manuscript. 


\section{Acknowledgements}

The present work was supported by the Swedish Medical Research Council, the Swedish Heart Lung Foundation, the Swedish Association for Allergology, the Swedish Foundation for Health Care Science and Allergic Research and the Royal Physiographic Society.

The 2-DE and MS-analysis took place at the SWEGENE Proteomics Platform in Lund, Sweden and the authors would like to thank professor Peter James (head of department) for the cooperation and Anna-Karin Påhlmann, Ulrika Brynnel and Liselotte Andersson for technical assistance and advice. Gustav Wallmark (Ludesi AB) is acknowledged for helping with the analysis in Ludesi 2D Interpreter.

\section{References}

I. Christodoulopoulos P, Cameron L, Durham S, Hamid Q: Molecular pathology of allergic disease. II: Upper airway disease. J Allergy Clin Immunol 2000, I 05:2 I I-223.

2. Svensson C, Andersson M, Greiff L, Alkner U, Persson CG: Exudative hyperresponsiveness of the airway microcirculation in seasonal allergic rhinitis. Clin Exp Allergy 1995, 25:942-950.

3. Benson M, Svensson PA, Carlsson B, Jernas M, Reinholdt J, Cardell LO, Carlsson L: DNA microarrays to study gene expression in allergic airways. Clin Exp Allergy 2002, 32:30I-308.

4. Gorg A, Weiss W, Dunn MJ: Current two-dimensional electrophoresis technology for proteomics. Proteomics 2004, 4(I 2):3665-3685.

5. Lindahl M, Stahlbom B, Tagesson C: Identification of a new potential airway irritation marker, palate lung nasal epithelial clone protein, in human nasal lavage fluid with two-dimensional electrophoresis and matrix-assisted laser desorption/ ionization-time of flight. Electrophoresis 200I, 22:I795-I800.

6. Ghafouri B, Stahlbom B, Tagesson C, Lindahl M: Newly identified proteins in human nasal lavage fluid from non-smokers and smokers using two-dimensional gel electrophoresis and peptide mass fingerprinting. Proteomics 2002, 2: I I $2-120$

7. Aas K, Belin L: Standardization of diagnostic work in allergy. Int Arch Allergy Appl Immunol 1973, 45:57-60.

8. Benson M, Strannegard IL, Wennergren G, Strannegard O: Interleukin-5 and interleukin-8 in relation to eosinophils and neutrophils in nasal fluids from school children with seasonal allergic rhinitis. Pediatr Allergy Immunol 1999, I 0: I78- I85.

9. Lamanda A, Zahn A, Roder D, Langen H: Improved Ruthenium II tris (bathophenantroline disulfonate) staining and destaining protocol for a better signal-to-background ratio and improved baseline resolution. Proteomics 2004, 4:599-608.

10. Back P, Nagard F, Bolmsjo G, Bengtsson S, James P: Automating gel image acquisition. J Proteome Res 2003, 2:662-664.

II. Levander F, James P: Automated Protein Identification by the Combination of MALDI MS and MS/MS Spectra from Different Instruments. J Proteome Res 2005, 4:7I-74.

12. Kersey PJ, Duarte J, Williams A, Karavidopoulou Y, Birney E, Apweiler R: The International Protein Index: an integrated database for proteomics experiments. Proteomics 2004, 4:1985-1988.

13. Samuelsson J, Dalevi D, Levander F, Rognvaldsson T: Modular, scriptable and automated analysis tools for high-throughput peptide mass fingerprinting. Bioinformatics 2004, 20:3628-3635.

14. Lindahl M, Stahlbom B, Svartz J, Tagesson C: Protein patterns of human nasal and bronchoalveolar lavage fluids analyzed with two-dimensional gel electrophoresis. Electrophoresis 1998, 19:3222-3229.

15. Benson M, Svensson PA, Adner M, Caren H, Carlsson B, Carlsson LM, Martinsson T, Rudemo M, Cardell LO: DNA microarray analysis of chromosomal susceptibility regions to identify candidate genes for allergic disease: a pilot study. Acta Otolaryngol 2004, I 24:813-819.

16. Benson M, Jansson J, Adner M, Luts A, Uddman R, Cardell LO: Gene profiling reveals increased expression of uteroglobin and other anti-inflammatory genes in nasal fluid cells from patients with allergic rhinitis. Clin Exp Allergy 2005, 35(4):473-478.
17. Benson M, Olsson M, Rudemo M, Wennergren G, Cardell LO: Pros and cons of microarray technology in allergy research. Clin Exp Allergy 2004, 34:1001-1006.

18. Madsen P, Rasmussen HH, Leffers H, Honore B, Dejgaard K, Olsen E, Kiil J, Walbum E, Andersen AH, Basse B, et al:: Molecular cloning, occurrence, and expression of a novel partially secreted protein "psoriasin" that is highly up-regulated in psoriatic skin. Invest Dermatol 1991, 97:701-7I2.

19. Jinquan $\mathrm{T}$, Vorum H, Larsen CG, Madsen P, Rasmussen HH, Gesser B, Etzerodt M, Honore B, Celis JE, Thestrup-Pedersen K: Psoriasin: a novel chemotactic protein. J Invest Dermatol 1996, 107:5-10.

20. Barondes SH, Cooper DN, Gitt MA, Leffler H: Galectins. Structure and function of a large family of animal lectins. J Biol Chem 1994, 269:20807-20810.

21. Hughes RC: Secretion of the galectin family of mammalian carbohydrate-binding proteins. Biochim Biophys Acta 1999, 1473:172-185.

22. Sano H, Hsu DK, Yu L, Apgar JR, Kuwabara I, Yamanaka T, Hirashima $M$, Liu FT: Human galectin-3 is a novel chemoattractant for monocytes and macrophages. J Immunol 2000, 165:2I 56-2I64.

23. Truong MJ, Gruart V, Kusnierz JP, Papin JP, Loiseau S, Capron A, Capron M: Human neutrophils express immunoglobulin $E$ (IgE)-binding proteins (Mac-2/epsilon BP) of the S-type lectin family: role in IgE-dependent activation. J Exp Med 1993, I 77:243-248.

24. Pancholi V: Multifunctional alpha-enolase: its role in diseases. Cell Mol Life Sci 200I, 58:902-920.

25. Baldo BA, Baker RS: Inhalant allergies to fungi: reactions to bakers' yeast (Saccharomyces cerevisiae) and identification of bakers' yeast enolase as an important allergen. Int Arch Allergy Appl Immunol 1988, 86:20I-208.

26. Ishiguro A, Homma M, Torii S, Tanaka K: Identification of Candida albicans antigens reactive with immunoglobulin $E$ antibody of human sera. Infect Immun 1992, 60:I550-I557.

27. Pucharcos C, Estivill X, de la Luna S: Intersectin 2, a new multimodular protein involved in clathrin-mediated endocytosis. FEBS Lett 2000, 478:43-5I

28. Van Den Berg DJ, Sharma AK, Bruno E, Hoffman R: Role of members of the Wnt gene family in human hematopoiesis. Blood 1998, 92:3189-3202.

29. Celis JE, Rasmussen $\mathrm{HH}$, Vorum H, Madsen P, Honore B, Wolf $\mathrm{H}$, Orntoft TF: Bladder squamous cell carcinomas express psoriasin and externalize it to the urine. J Urol 1996, I55:2105-2| I2.

30. Myal Y, Gregory C, Wang H, Hamerton JL, Shiu RP: The gene for prolactin-inducible protein (PIP), uniquely expressed in exocrine organs, maps to chromosome 7. Somat Cell Mol Genet 1989, 15:265-270.

31. Gaubin M, Autiero M, Basmaciogullari S, Metivier D, Mis hal Z, Culerrier R, Oudin A, Guardiola J, Piatier-Tonneau D: Potent inhibition of CD4/TCR-mediated $T$ cell apoptosis by a CD4-binding glycoprotein secreted from breast tumor and seminal vesicle cells. J Immunol 1999, 162:2631-2638.

32. Ingenbleek Y, Young V: Transthyretin (prealbumin) in health and disease: nutritional implications. Annu Rev Nutr 1994, 14:495-533.

33. Johansson SG, Deuschl H: Immunoglobulins in nasal secretion with special reference to IgE. I. Methodological studies. Int Arch Allergy Appl Immunol 1976, 52:364-375. 